\title{
Limitations on the Right of a Municipality in California to Condemn a Public Utility
}

M ${ }^{A} \mathrm{Y}$ a municipality in California condemn for the use of itself $\mathrm{V}$ and its inhabitants a public utility company's property, which is dedicated to the public use, not only of the inhabitants of the municipality, but also of the inhabitants of the territory outside the municipality?

Under the provisions of section 47 of the Public Utlities Act, the municipality intending to condemn has the right, by proper proceedings, to have the just compensation to be paid therefor fixed by the Railroad Commission, but after the compensation has been so fixed, the right to condemn is to be determined by a court of competent jurisdiction, in an action instituted and maintained under the provisions of the Code of Civil Procedure relating to the exercise of the right of eminent domain.

The basis of the right of municipal ownership of a public utility is found in section 19 of article XI of the Constitution which provides :

"Any municipal corporation may establish and operate public works for supplying its inhabitants with light, water, power, heat, transportation, telephone service or other means of communication. Such works may be acquired by original construction or by purchase of existing works, including their franchises, or both ...."

and in section 1 of the act of May 1, 1911, ${ }^{2}$ which provides:

"Any municipal corporation of the State of California may acquire, construct, own, operate or lease any public utility. A public utility, as the term is used herein, is defined to mean the supply of a municipal corporation alone, or together with the inhabitants thereof, or any portion thereof, with water, light, heat, powver, transportation of persons or property, means of communication or promoting the convenience of the public . . ."

A municipality then being authorized to undertake the ownership and operation of public utilities, the right to condemn property to be devoted to such uses is found in section 1001 of the Civil Code which provides:

"Any person may, without further legislative action, acquire private property for any use specified in section twelve hundred and thirty-eight of the Code of Civil Procedure either by con-

1 Cal. Stats., 1917, p. 261.

2 Cal. Stats. 1911, p. 1394. 
sent of the owner or by proceedings had under the provisions of title seven, part three of the Code of Civil Procedure; and any person seeking, to acquire property for any of the uses mentioned in such title is 'an agent of the state,' or a 'person in charge of such use' within the meaning of those terms as used in that title,"

and in section 1238 of the Code of Civil Procedure which specifies the public uses in behalf of which the right of eminent domain may be exercised.

This section, as originally enacted, specified, as declared by its title and its opening paragraph, only the uses or purposes for which, or the objects for the construction of which the right might be exercised. It did not purport to specify the nature or character of the property which might be taken, that being specified in section 1240. But since its original enactment it has been repeatedly amended by the insertion of many phrases with the apparent purpose of attempting to specify the character of property which may be taken. These amendments have been ineptly made, through a failure to appreciate that the section refers only to uses. They should have been added to section 1240, if in fact it was necessary to add to that section to give the right to condemn such property. In its present form this section in parts is difficult, if not impossible to construe, as witness the following:

". . . the right of eminent domain may be exercised on behalf of the following public uses: . . .

"13. . . . lands, buildings or rights of any character in water

or any other character of property necessary for generation, transmission or distribution of electricity."

It is apparent that lands, water rights and property are neither uses nor purposes, nor objects for the construction of which the right of eminent domain may be invoked. They are intended to be descriptive of the things, which may be taken by the exercise of that right.

It is, however, unnecessary for the purposes of this article, to determine the proper construction and effect of this and similar phrases inserted by amendment. It is of importance to note them simply to preface the statement, that they do not broaden or limit the scope of section 1240, which alone is applicable in the determination of the right of a municipality to expropriate the property of a public utility company, and the limitations on that right, which are the subjects of this discussion. of 1913 .

\& The italicized words were inserted in subdivision 13 by the amendmeut 
Section 1240 specifies what property may be taken for public use. The portions of this section pertinent to this discussion are as follows:

"The private property which may be taken under this title includes: ...

"4. Property appropriated to public use; but such property shall not be taken unless for a more necessary public use than that to which it has already been appropriated; provided that where any such property has been so appropriated by any individual, firm or private corporation .... the use thereof by a county, city and county, incorporated city or town, irrigation or municipal water district, for the same public purpose to which it has been so appropriated, or for any other public purpose, shall be deemed more necessary uses than the public use to which such property has already been appropriated; and provided, further, that where property already appropriated to a public use or purpose by any person, firm or private corporation, is sought to be taken by a county, city and county, incorporated city or town, irrigation or municipal water district, for another public use or purpose, which is consistent witb the continuance of the use of such property or some portion thereof for such existing purpose, to the same extent as such property is then used, or to a less or modified extent, then the right to use such property for such proposed public purpose, in common with such other use or purpose, either as then existing, or to a less or modified extent, may be taken by such county, city and county, incorporated city or town, irrigation or municipal water district, and the court may fix the terms and conditions upon which such property may be so taken, and the manner and extent of the use thereof for such public purposes. . . B But property appropriated to the use of any county, city and county, incorporated city or town, irrigation or municipal water district may not be taken by any other county, city and county, incorporated city or town, irrigation or municipal water district, while such property is so appropriated and used for the public purposes for which it has been so appropriated."

Section 1241 of that Code provides that before property can be so taken it must appear that the use to which it is to be applied is authorized by law, that the taking is necessary to such use and, if it has already been appropriated to a public use, that the use to which it is to be applied is a more necessary public use. This section end: with a proviso identical with the last proviso in section 1240 .

The right of a municipality to expropriate the property of a public utility company is therefore clearly given unless such property has been appropriated to the use of another municipality and is being so used.

Frequently, and almost invariably in the case of the large electric power companies, it happens that the property of a public utility 
company lying within the corporate limits of a municipality, while appropriated to the use of the inhabitants thereof, is also appropriated to the use of the inhabitants of a large outlying territory. This constitutes an appropriation, not only to the use of the municipality in which it is located, but to the use of other counties, cities and towns within the meaning of the proviso common to sections 1240 and 1241 for as said in Mono Power Co. v. City of Los Angeles :4

"The terms 'county, city and county, incorporated city or town,' represent certain political subdivisions of the state. They also represent the inhabitants collectively."

In that case the United States Circuit Court of Appeals for the Ninth Circuit held that the City of Los Angeles could not condemn the property of a public utility company situated entirely outside its corporate limits, that property being then appropriated to the use of numerous other cities and towns, saying:

". . . we must hold that it was the purpose of the Legislature to provide that property of a private corporation, as well as property of a municipal corporation, appropriated to the public use in one county, may not be appropriated to a public use by any other county, city and county, while such property is so appropriated and used."

It must be admitted that there is a difference between the facts in that case, in which the property sought to be taken lay wholly outside the corporate limits, and was not, either in whole or in part, appropriated to the public use of the municipality seeking its condemnation, and in the case in which the property lies wholly within the corporate limits and is appropriated to the public use of the municipality seeking its condemnation, in conjunction with the public use of adjoining municipalities and counties.

But does this difference in facts supply any reason why the same rule should not be applied?

It is true that it is said in the case of East Bay M. U. Dist. v. Railroad Con..:

"It is also contended by counsel representing the water company that under the provisions of sections 1240 and 1241 of the Code of Civil Procedure, as amended in. 1915, the petitioner has not the legal right to condenin the property of the water company dedicated to the use of territory and peoples without the district, and it is asserted that the case of Mono Power Co. v. Los Angeles, 284 Fed. 784, is conclusive in favor of the water

4 (1922) 284 Fed. 784, 793.

5 Ibid, 795. See 11 California I. Rev. 366 (1923).

6 (1924) 194 Cal. 603, 229 Pac. 949. 
company's contention. We cannot so conclude. In that case the city of Los Angeles was seeking to condemn the property of a public utility which was dedicated to the use of communities lying wholly without the boundaries of the city of Los Angeles and no part of which had ever been dedicated to the use of the city of Los Angeles. It was proposed to take the property wholly away from the territory and peoples to which it had been dedicated and devote it to territory to which it had never been dedicated. . . . The declared purpose of the city, therefore, brought the case within the prohibition of said sections 1240 and 1241, wherein it is provided: 'But property appropriated to the use of any county, city and county, incorporated city or town or municipal water district, may not be taken by any other county, city and county, incorporated city or town, or municipal water district, while such property is so appropriated and used for the public purposes for which it has been so appropriated' .. . . It is here proposed to continue the use of the water to the same territory to which it has heretofore been appropriated. The territory and the peoples thereof are not to be disturbed in the use to which the water is now put and are to enjoy an uninterrupted use thereof, if the petitioner succeeds in its purpose. In other words, the change will result not in the disturbance of the use or appropriation of the water but in the agency authorized by law to administer the trust. We find nothing in the sections referred to which would prohibit such a change."

That case came before the Supreme Court on petition filed by a municipal utility district for a writ of mandate to require the Railroad Commission to make a valuation under the provisions of section 47 of the Public Utilities Act of certain properties which it contemplated acquiring under condemnation. That court denied the writ upon the ground that a public utility district under the provisions of section 23a of Article XII of the Constitution as it then existed, prior to the amendment of 1924, was not qualified to require the commission to make such valuation. The portion of the court's opinion above quoted is an obiter dictum; the question decided not being whether the utility district had the right to condemn but whether it was qualified to petition the commission to make the valuation.

Mr. Justice Shenk, who wrote the opinion in that case, apparently has failed to give full consideration to the wording of the prohibition against taking by one municipality of property already appropriated to the use of another, contained in sections 1240 and 1241 , quoted by him. The prohibition is not that the existing appropriation of such property may not be terminated or disturbed but that property so appropriated may not be taken. The word "taken" refers to owner- 
ship or right of possession. In 37 Cyc. 665 the word "take" is defined as

"To receive; in its general sense, to get into one's possession or power; to acquire; to obtain; to procure; in the active sense, to lay hold of ; seize with hands or otherwise; to obtain possession by force or artifice; to get the custody or control of; to reduce to one's power or will; to receive what is offered; to lay hold of; a word which, applied to land, implies to gain or receive into possession; to seize; to deprive one of the possession; to assume ownership ...."

The word "take" is used throughout the title of the code relating to eminent domain and always in the sense of acquiring ownership. This statutory provision then is not that the users of the utility shall not be deprived of the use, but that the owner of the utility shall not be deprived of ownership; it is not that the use may not be taken, but that the property may not be taken.

It is true that the object of the statutory provision that one municipality may not take property appropriated to the public use of another municipality is to insure to the municipality, which is enjoying the use, that it shall not be deprived thereof, but the manner in which this object is accomplished is by forbidding the taking of the property from the owner. The statute makes no exception in favor of property situated within the confines of the condemning municipality, as against that situated outside. Property lying outside of a municipality and used only by the inhabitants of the outlying district might be acquired by the municipality and the use continued to the outside district, yet it may not be taken by condemnation. If the property be acquired by the municipality in which it is situated, the outlying district formerly served therefrom, might be deprived of the use or might be continued in the use, in exactly the same manner, as though the property lay outside.

Section 19 of Article XI of the Constitution and the act of May 1, 1911, permit a municipality, operating a public utility, to furnish service to inhabitants outside its boundaries whenever it develops water, heat, light or power in excess of that which is necessary for its local use. It therefore follows that if the expropriating municipality has a plant and distributing system and is producing an excess of water or electric energy, it may extend its distributing system to serve those communities. This is undoubtedly true, if it has such a plant and system, but it does not follow that therefore it can condemn such a plant and system. The statute expressly says that it cannot take property which is appropriated and used for public purposes by another municipality. It does not say that it can take property 
so appropriated and used provided that it undertakes to continue equal present and prospective service to such municipality.

It may be contended that the expropriating municipality can permit the public utility corporation to share in the use of that portion of its system proposed to be expropriated so that it can continue service to these communities.

If the court can decree a condemnation on such terms, its power to so decree must be found in the proviso of section 1240 of the Code of Civil Procedure above quoted, to the effect that where property already appropriated to a public use or purpose is sought to be taken by a municipality for another use or purpose, which is consistent with the continuance of the use of such property or some portion thereof for such existing purpose, to the same extent as such property is then used, or to a less or modified extent, then the right to use such property for such proposed public purpose, in common with such other use or purpose, either as then existing or to a less or modified extent, may be taken by such municipality and the court may fix the terms and conditions upon which such property may be so taken.

It will be seen that this proviso gives the power to acquire the right to use a public utility jointly with the owner thereof when that can be consistently done; that is to say the owner of the public utility may be permitted to continue in the ownership and use of the property, burdened, however, with the right of the municipality to share in the use. Illustrations of such joint use would be the use of the poles of an electric company to carry the wires of a municipally owned electric system or the use of the tracks of a street railway company by the cars of a municipal line. Such use would not be inconsistent with the use of such property by the owner thereof.

It is quite true that such common use by the municipality and the public utility corporation might be made in some cases, but in a case such as an electric power company having within the municipality a generating plant, substations, transmission and tie lines, the mumicipality certainly could not use such a system to generate and distribute electric energy within its boundaries, consistently with its common use by the company to generate and distribute electric energy outside the boundaries.

Certainly one could not be compelled by virtue of anything contained in the statute, to permit the other to operate its interest therein as its agent. Apparently the only practical solution would be a requirement that the city furnish energy to the original owner at a fixed rate for distribution to the outlying communities, but there is 
no basis in the statute authorizing the entry of such a decree. This would not be the common use which the statute contemplates. It would be the establishment of the relation of vendor and purchaser. There would be no "continuance of the use" by the company.

It may also be contended that severance or other damages and compensation. will be paid to the public utility company so that it can construct the necessary facilities to continue such services.

To so contend is simply to argue in a vicious circle. If property is already appropriated to the public use of one municipality it cannot be taken by another. This plain mandate of the statute cannot be avoided by the offer of the municipality, undertaking to expropriate, to finance the construction of facilities in substitution for those taken.

Examining the entire body of constitutional and statutory law pertaining to municipal ownership of public utilities and the power of exercising the right of eminent domain by municipalities for their acquisition, two things are apparent: First, that the law favors municipal ownership and has given to municipalities the broadest power to acquire existing utilities, and, second, that the law has jealously protected and safeguarded municipalities and communities from encroachment on their rights by other municipalities and communities, and has forbidden the exercise of the right of eminent domain to take from the owner the public utilities which serve them, whether municipally or privately owned. In fact the only limitations iniposed on the exercise of this sovereign power by a municipality is that it shall not expropriate the property of a public utility company, if its needs can be satisfied by sharing with the company in a joint use of the property, and that it shall not so exercise that power as to take from its owner, a public utility furnishing service to other communities. These are fixed and absolute limits on the exercise of the right.

A telephone system constitutes an apt illustration of the essential unity of a utility dedicated to a regional public use. The service renclered to each consumer is both incoming and outgoing. Each line, switchboard and instrument may be used by each subscriber to send or receive communications to or from any other subscriber. Each part is obviously appropriated to the public use of the region. No part is appropriated exclusively for local use. The severance of any part, to that extent diminishes the use of the whole.

The large cities of California have recently embarked in the business of generating and distributing electric energy as adjuncts to their water supply systems. They look with covetous eyes on 
these portions of the systems of privately owned electric companies, within their boundaries which could be readily converted to use to distribute energy generated in their mumicipally owned plants. Hence the right of the cities to condemn such portions of those systems as may be useful to them is at this time a question of prime importance and interest.

An electric power system, although its service is rather an incoming than an outgoing service, possesses in large measure the quality of essential unity.

As a business of generating, transmitting and distributing electric energy has been developed in California, its basis is one or more large and expensive stationary generating plants for the conversion of water power into electric energy, the water power being frequently supplied from artificial lakes constructed at an enormous cost. From the plant the energy is transmitted under high voltage over long and expensive pole lines to substations, where it is transformed to a lower voltage and distributed to the consumers. If two or more generating plants are used they are inter-connected by means of the transmission and tie lines and substations, so that energy wheresoever generated may be transmitted to any part of the system for distribution. The service extends over vast areas to be reckoned not in terms of municipalities, but of counties and frequently of states. The companies owning these public utilities are perforning an important, necessary and almost essential service to a large population. Industries have grown up and territory has been settled in reliance on their ability to furnish electric energy, and the economic welfare of the state is largely dependent on their efficient and continued administration.

Although a transmission line may run to and terminate in a given municipality, it is not for the exclusive use of that municipality. Though convenience may dictate the erection of a substation there, it is not appropriated to the exclusive use of that municipality. These lines and substations are integral parts of the entire system, interdependent just as are the nerves, veins and arteries of the human body.

It may be very convenient and practical for a municipality, from its own selfish standpoint, to lop off or excise an integral portion of an entire system for its own use. Such portion can be readily converted into an independent system. The municipality is saved the trouble, annoyance and delay of building its own system and securing its own rights of way. It acquires that which at small additional expense can be readily and speedily made an operative and function- 
ing unit. But in common justice should it be allowed to do so at the expense and damage of the inhabitants of the great area served from the entire system? Should it be allowed to cripple that system to attain its selfish ends?

It is true that severance damages must be paid, but the people outside the municipality whose service has been terminated or crippled are not compensated. Can they compel the public utility company, after the heart or an integral ganglion of its system has been cut out, to reconstruct new transmission lines, substations and possibly generating plants to continue the service? It may be that the lessened patronage will not warrant such new construction; that no adequate returns can be derived from the investinent. But even if such construction can be compelled, much time will be consumed, so there must be an inevitable deprivation or crippling of service for a time at least.

A public utility corporation is to a certain and very large degree a trustee for the benefit of the public which it serves. Upon it has been conferred the sovereign right of eminent domain. This right has been granted it not for its own use and benefit, but that by its exercise it may better serve the public. Because of this peculiar relation to the public, because it has been entrusted with this sovereign right, the state has the right and power to regulate and control it and to enforce the public right in and to its property and services. And such a company having once appropriated its property to the public use and service cannot cease to function and serve the public either in whole or in part without the consent of the public, as represented by the state. Therefore such corporation as trustee of a public trust is fully justified in resisting any attempt not clearly authorized by law, to deprive it of property, if such expropriation would result in ending or impairing its services to such portion of the public served by it, as do not join in the attempt to take that property and the courts would seem to be cbarged with a special duty to protect the rights of those consumers who might be injured by such taking.

If a public utility corporation were to negotiate with a municipality for the sale of all its facilities within the corporate limits, such facilities being used not only to serve the municipality and its inhabitants but also the inhabitants of outlying communities, and were to apply to the Railroad Commission for an order authorizing it to consummate the sale, would the commission authorize it, against a showing by the outlying communities, that the company's service to them would be impaired or destroyed? Would not the Commission make such an order, only when and if adequate provision had been 
made for service to the outlying communities of at least the same character as that then furnished to them and with at least the same potentialities of increased service to meet their future growth and necessities? Section 51 of the Public Utilities Act ${ }^{7}$ expressly provides:

"No railroad corporation, street railroad corporation, pipeline corporation, gas corporation, electrical corporation, telephone corporation, telegraph corporation, or water corporation shall henceforth sell ... . the whole or any part of its railroad, street railroad, line, plant or system, necessary or useful in the performance of its duties to the public ... without having secured from the Commission an order authorizing it so to do."

But proceedings in eminent domain are in invitum. The Railroad Commission has power only to fix just compensation and severance damages to be paid to the public utility corporation. It cannot prescribe terms for the protection of the public of the outlying communities, as a condition upon which the condemnation shall be allowed. After just compensation and damages are so fixed the municipality institutes its action in court to condemn. And in such action the court has no power to prescribe sucl terms and conditions.

It therefore seems obvious that a sale cannot be compelled by proceedings in eminent domain which could not be voluntarily made by agreement of the parties.

It is true that the operation of a law will not be restrained or suspended by the courts because it is economically unsound, or because the exercise of the rights by it conferred on one person or community will operate to the economic disadvantage of other persons or communities. But it is proper to consider the economic trend of the law as a guide to its construction. If it is ambiguous, certainly it is not to be presumed that the legislature intended to impair the prosperity of certain portions of the state in order to give advantages to others, and such a construction should be given as will render its operation economically sound. Statutes giving the state's right of eminent domain to individuals or public or private corporations are to be strictly construed. The burden is on the plaintiff in condemnation to establish the ownership of the right to take and no presumptions are to be indulged in for the benefit of the plaintiff. If the rule of strict construction is applicable in cases in which it is souglit to expropriate property not appropriated to a public use, how much stronger is the reason for the rule when property already appropriated to a public use is sought to be taken. Those being

7 Cal. Stats., 1915, p. 149. 
served from such property have rights as well defined as the owner. They are entitled to the protection of the state and its courts and may not be deprived of those rights, unless the power is clearly given by the statute. Hence it follows that no power should be read into the statute by implication or intendment which would give to one municipality or community an advantage at the expense of others.

If one municipality may expropriate a portion of such a system, other municipalities may, in like manner, expropriate other portions. With what result? Finally the original owner will be left with disjointed fragments of a system, and the purchase price and severance damages paid by the condemning municipalities. A system which has been built up with foresight and careful planning, as a comprehensive whole, to serve a large territory; which as a whole is necessary to the economic welfare of the state; which as a whole and only as a whole, can be economically handled; which can rectify shortage of power in one district by transmission of surplus power from another; which can serve the public at a low rate, because of an overhead, small in proportion to the business transacted and the generation of energy on a large scale, will be dismembered into separate operative units, each carrying an abnormally large overhead and therefore increasing the rate to the consumer. The original owner will be left with large and costly generating plants, far in excess of the needs of its patrons or its ability to distribute. It is true that, in theory at least, it will have been compensated for its loss, but that will not justify the economic loss to the state, on rendering large and expensive plants of diminished or no utility.

Certainly the law does not contemplate such an orgy of destruction of values, necessarily increasing the rate to consumers and especially rural consumers, in the name of municipal ownership.

The law has wisely provided that where property has been appropriated to the public use of the inhabitants of a certain locality it shall not be taken from its owner for the use of the inhabitants of another locality or the use of the inhabitants of only a part of the same locality.

It: may be contended that since the acquisition by a municipality of a public utility by condemnation, although in invitum, is still a sale, therefore after the judgment of condemnation is entered and before payment of compensation and damages is made, application must be made to the Railroad Commission, under the provisions of section $\mathbf{5 2}$ of the Public Utilities Act, for an order authorizing such sale, and that on the hearing of such application the Commission may 
order authorization, on condition that the municipality shall provide for the continuance of service to outlying communities. But section 47, subdivisions 8 and 9,8 expressly provide that the judgment of the court shall be final. When judgment is entered the obligation to sell and the right to purchase is fixed and absolute, and the municipality is given the right of immediate possession upon payment of the just compensation.

The question whether or not there are limitations on the right of a municipality to condemn a portion of a regional system which physically is of purely local use within its confines is also debatable.

Take the case of an electric power company deriving the major portion of its energy from a hydro-electric plant. Whether or not the plant is supplying energy up to the full maximum demand which it is designed to supply, with the highest possible load factor, the cost of its operation is practically an invariable. Fixed charges, such as interest, sinking fund and depreciation, and also operating costs, are constants. There are no items of fuel or raw material entering into the cost of production. So that whether consumption or load factor increases or decreases, the total cost of production remains stationary or varies within very narrow limits, not at all in proportion to the variance of consunption or load factor. When the consunption is large, coupled with a high load factor approximating the capacity of the plant, the cost of production per kilowatt hour supplied is at its lowest. But when the consumption or the load factor diminishes, the cost of production per kilowatt hour increases.

A hydro-electric plant, with its appurtenant transmission and distributing lines, constructed for the public use of a region is of a type and size commensurate with the probable consumption and maximum demand of that region, with a proper margin to take care of increase. If such a system is operated on the basis of the use which it is designed to supply, it has a high efficiency and its rates are relatively low. If, however, the cutting off of a part of that system results in lowering either consumption or load factor, its efficiency is lowered and the rates must be raised to secure a proper return on capital invested. The system efficiency is both physical and economic.

Consequently we may look on the appropriation of the system to a public use as an econonic as well as a physical appropriation. Hence it would seem logical to consider the econonic effect of severance, in the determination of the proper interpretation of the law and its limitations.

8 Cal. Stats., 1917, p. 266, 267. 
From an economic standpoint the system as a whole is appropriated to the use of the region, although certain parts, from a physical standpoint, may be appropriated to the use of individual localities within the region. Collective use alone insures the greater efficiency in operation and the lower rates. A separation into disconnected units throws the project out of economic balance, resulting possibly in a power plant out of all proportion to the present or prospective consumption or maximum demand. It follows that all the parts collectively constitute an economic unit, essentially indivisible.

It may be contended that in case this separation is made as a result of condemnation of a part of the system, severance damages will be paid, which will compensate the owner for the loss in consumption and the diminished load factor, so that rates will not be changed.

In proceedings to condemn property already devoted to a public use, the users are essentially interested, although not parties to the action. If condemnation and severance of a portion of a system will result in raising prices to consumers served from the remainder of the system, there will be an interference with their enjoyment of the public use, less in degree, but just as absolute as total deprivation. Their right to non-interference is guaranteed by the law, not by requiring that they shall be made parties and compensated in damages, for that would be impracticable, but by the easily enforceable provision that the property which serves them shall not be taken from its owner. Therefore the contention that severance damages paid to the owner will compensate for loss in consumption and diminished load factor and accordingly rates will not be changed, is specious, if the premise that there is an economic appropriation to the public use is sound, for the law expressly provides that the property shall not be taken at all, not that it nuay be taken on payment of severance damages.

From the foregoing it would seem that a municipality cannot condemn the property of a public utility corporation situate within its limits, which is appropriated to the public use of the inhabitants of an area greater than that embraced within its confines. Such portions of its property as are used for the service of the greater area in general cannot be condemned. If any portion may be expropriated, the right of condemnation can apply only to such portions as are distinctly only of local use within the municipal confines and which can be separated from the system without impairing its general utility, either physically or economically. But all facilities 
which are integral parts of the system as a whole or of the system insofar as it covers an area of greater extent than the municipality, are clearly protected from condemnation by the municipality by the express provisions of section 1240 and 1241 of the Code of Civil Procedure.

Thomas H. Breeze.

San Francisco, California. 